Digital Press Social Sciences and Humanities

Phenomences of Dance Competition Winners at the FLS2N Event in West Sumatera Province (the Study of the Result of Extracurricular Program)

Venny Rosalina, Gustia Arini E and Herlinda Mansyur

Proceeding of The Non-Formal Education International Conference 2020

Alim Harun Pamungkas, Jamaris, Solfema (eds) 


\title{
Phenomences of Dance Competition Winners at the FLS2N Event in West Sumatera Province (the Study of the Result of Extracurricular Program)
}

\author{
Venny Rosalina*, Gustia Arini E, and Herlinda Mansyur \\ Prodi Pendidikan Tari, Jurusan Sendratasik Universitas Negeri Padang, Indonesia \\ *e-mail: vennyrosalina91@gmail.com
}

\begin{abstract}
The phenomenon of the development of dance in West Sumatra always has a shift in accordance with the influence of the times and cultural demands. This can be proven through the most prestigious annual dance event in Indonesia, namely FLS2N. This event proves how the development of dance at the youth level every year. Dance Extracurricular Activities as Non-Formal Education are the main forum for fostering creativity and instilling Minangkabau values in a dance movement. Dance education from adolescence must be implemented in maintaining the values and successors of the next generation so as not to erode the cultural values that exist in Minangkabau. This study aims to analyze the extent to which the development of dance at the school level. See how the efforts and development of dance in the learning room to attend the annual event. The shift in the past few years has resulted in female dancers no longer getting a place in the event because they are considered the work that was born violating cultural norms. Looking at the history of the development of Minangkabau dance, women are actually the most influential people in the development of Minangkabau dance.
\end{abstract}

\section{Keywords}

Phenomenon, dance development, gender, Minangkabau.

\section{Introduction}

Festival dan Lomba Seni Siswa Nasional (FLS2N) is an event that is always awaited by the school level in Indonesia, both at the elementary, junior high and high school levels. This government program in supporting the creativity and talents of students is carried out once a year, and every year it is held in different cities.

The spirit of FLS2N was greeted enthusiastically in West Sumatra, each school showing each other their skills to prove who is the best in terms of creativity. Competition between schools produces excellent work every year. This competition refers to creativity to support the cultural education value of each school so as to produce and develop competitive attitudes, cooperation and sportsmanship in students who have a global perspective and make friends in the process of preserving Indonesian cultural arts (Sinaga, 2016; Sinaga, Maestro, Winangsit, \& Yensharti, 2019).

Every school in West Sumatra has prepared a special budget for FLS2N. Quality works certainly require experts or professional trainers in their fields. The trainers in West Sumatra usually come from students of the Padang Panjang Indonesian Art Institute (ISI), Sendratasik from UNP and there are also self-taught artists who are really in the field. The Junior High School level has five branches of competition, namely the Dance Creativity Festival, Traditional Music, Guitar Duet, Solo Singing and Poster Designing. Each student who passes the selection at the school level has the right to participate in the five competitions. The dance creativity branch is one of the five branches that is most in demand by competition participants. Dance as a text is something that can be read and interpreted (Sriyadi, 2013). This means that a dance that crosses the stage is not just a form of movement arrangement and technical skills or virtuosity of the dancers, but requires a deepening of the content, and it must all arrive at the target or "communicative meaning" to the audience (Hadi, 2001, p. 9). 
The system for selecting dancers in schools is objective based on the basic abilities of each child, and this election has the right to be followed by all active students, both boys and girls who are still in class VII or VIII. After five potential dancers are selected or according to the criteria, then it is the trainer's job to conceptualize the work according to the FLS2N technical guidelines for the SMP level. The training process takes at least three months. Starting from the concept of work, music, costumes, property, makeup and costumes are the results of the trainer's thoughts. The trainer has full responsibility for what will be presented later, apart from making the school proud, this is also a place for the trainers to show their quality.

Recently, the development of the junior high school dance branch has always been a topic of conversation among coaches, schools and artists in West Sumatra. The reason is that there has been an interesting upheaval in recent years, namely, the winner in the past five years wearing male dancers for a sequence. This raises a lot of questions among trainers and artists, why do school participants who wear male dancers always win competitions at the provincial level in West Sumatra? Even though there are also many excellent works using female dancers and a mature concept that always runs aground in judging at the Provincial level. When examined based on their work and techniques, women at the junior high school level are better at moving than men starting from their flexibility, taste, expression and other factors, they are more in control. This has been the big question so far.

The history of choreographers and dances from West Sumatra does not have the dominant male dancer literature in its development. Because Minangkabau women get a unique place from a cultural point of view using the maternal lineage system (matrilineal). The concept of matrilineal culture offers an attraction for the position of women to develop their creativity. This concept is thought to be fertile ground for the growth of androginic attitudes in Minangkabau women (Kuardhani, 2000). This of course influenced the Minangkabau choreographer in his life as an artist. The Minangkabau choreographers referred to are Hoerijah Adam, Gusmiati Suid and Syofyani Yusaf. The three female dancers and choreographers of Minangkabau prove that the strong or characteristic dances in Minangkabau (West Sumatra) are controlled by women. This has been passed down from generation to generation to the present day. Based on the research background, the researcher formulated the problem to be studied, namely what are the criteria for judging judges in the FLS2N competition at the Junior High School Level in West Sumatra Province?

\section{Methods}

Educational research is an activity directed at developing scientific knowledge about events of interest to education (Manab, 2015). The aim is to find general principles, namely the interpretation of behavior that can be used to explain, predict, and control events in the educational environment.

The research approach used is descriptive analytic, which means that the interpretation of the content is made and compiled systematically / thoroughly and systematically. The data obtained in the form of words, pictures, or behavior is not written in numbers or statistical figures, but is still in a qualitative form which has a meaning that is richer than just numbers or frequencies. (Margono, 2005, p. 39).

The target informants in this study are the jury members who have been active in recent years and also schools in the city of Padang which have won championships at the provincial level. The informant is Ali Sukri, a Sumbar choreographer and also a dance lecturer at ISI Padangpanjang, while the representative jury from education is Indra Yuda, a choreographer and also a lecturer at UNP Padang. The data collection methods used in this study took various forms, ranging from observation, data collection, retrieval of related documentation about the implementation and performance of the provincial competition.

The process of analyzing data by examining all available data from various sources that has been obtained from field research, namely from interviews, observations, personal documents, official documents, pictures, photos, and so on (Moleong in Sumaryanto, 2010: 103). Data on the winners, the concept of hope, the coach and the accompanying teacher. Data on participants who did not win was also needed as a comparison of the work worthy of whether or not the winner was determined based on technical guidelines. The results of the data analysis are then compiled in the form of a report with a descriptive analysis technique, namely by describing the information or data that has been collected and analyzed based on existing theories. 


\section{Result and Discussion}

\subsection{Gender Phenomena in the context of FLS2N Dance Creativity in West Sumatra}

This study examines an aspect of how the development of the Minangkabau dance culture from its character to the competition. Starting from dance as a ritual until today, the art of dance becomes a space to strengthen cultural characters with the influence of popular culture in its development. The following describes a literature review of several writings or the results of previous research.

According to Raymond Williams in John Storey, who said that popular culture refers to a "work of art and intellectual practice, especially artistic activities and a certain view of life of society in a certain period or group". Furthermore, William, popular culture is a commercial culture which is the impact of mass production, then the instantaneous mass production that appears along with the development and growth of society is what makes one of the elements of culture begin to shift its position in the midst of its own supporting society (2018, pp. 2-3).

Adolph S. Tomars (1964) in his writing entitled "Class System and The Art" states that the presence of a class or group of people will also present a distinctive art style and form, in accordance with the aesthetic tastes of certain groups, for example the presence of a group or corporate class that presents collective art. variety and the presence of competitive groups or classes that present art that has a characteristic individual expression.

Several previous studies are very important to compare the validity of the research. In general, there is no previous research that examines directly how the assessment in the dance competition event (FLS2N), but many previous studies have revealed the status or character of Minangkabau dances and choreographers. The literature related to the following research is the following articles:

Desfiarni and Fuji Astuti's research entitled Koreografer Wanita Sumatera Barat: Suatu Tinjauan March 29, 2007 states that Minangkabau female choreographers at this time can be said to have got a much more strategic place when compared to previous choreographers (Astuti, 2003, 2004). This research describes how Minangkabau female choreographers struggle from a position that does not have a place in society to be able to prove and break the society's view of women who work. It can be concluded how much influence women have in making dance works and even in producing works that carry out women's character and dances in facing cultural challenges in society. This research can be said to be a foundation for researchers to explore the extent of literature and the role of women in the history of Minangkabau dance (Indrayuda \& Ardipal, 2017).

Surheni made a study in 2015 with the title Empat koreografer Minangkabau: dibaca dalam teks Matrilineal dan Patrilineal, it explains that Minangkabau women have a place in the community where Minangkabau dance reformers are known: Huriah Adam, Gusmiati Suid, and Syoviani Bustamam. Explains how these figures are well known among Indonesian artists for their achievements

The two studies above generally have the same object about how the role of women in the development of Minangkabau dance. Starting from the two studies above, it is clear that this has a big impact on what will be studied. As a foothold, the research material above becomes a stepping stone to see a cultural shift or it can be said the return of old understanding in the development of Minangkabau dance, one of which is in the FLS2N event where the goal is to develop culture (Indrayuda, 2017).

Movement characters performed by women tend to have limitations compared to men's movements which have greater space and strength. For example, jumping and opening your legs wide is considered not in accordance with the ethics and aesthetics of the Minang dance because it is considered the loss of the female side because it suits male dancers more. In addition, the contribution of the duo baleh is studied in a dance work, indirectly limiting the space for movement or the creativity of the choreographer / trainer in choosing a movement in its development. Because it is seen from the situation in the field that movements that have great strength and space for movement are considered more suitable for male dancers, while there is also a conversation when the movements in dance work show the dynamic character of female movements, there is a perception that their movements have no power or quality of motion (Indrayuda, 2015). Meanwhile, when a work is performed with male dancers, there are no problems and can be considered legitimate. This can be seen in Figure 1 and 2 below: 


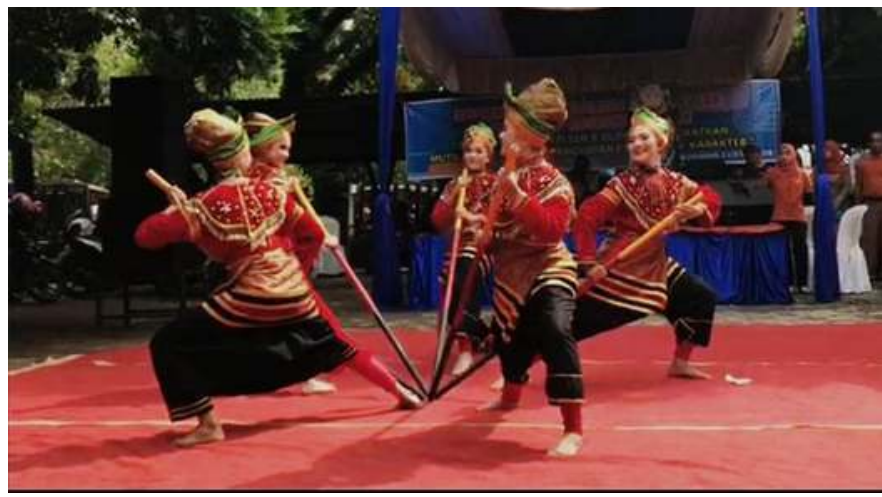

Figure 1. Participants of the Women's Group from SMPN 1 Payakumbuh, received 2nd Place in FLS2N Payakumbuh City (Photo: Hernando Saputra, 2018)

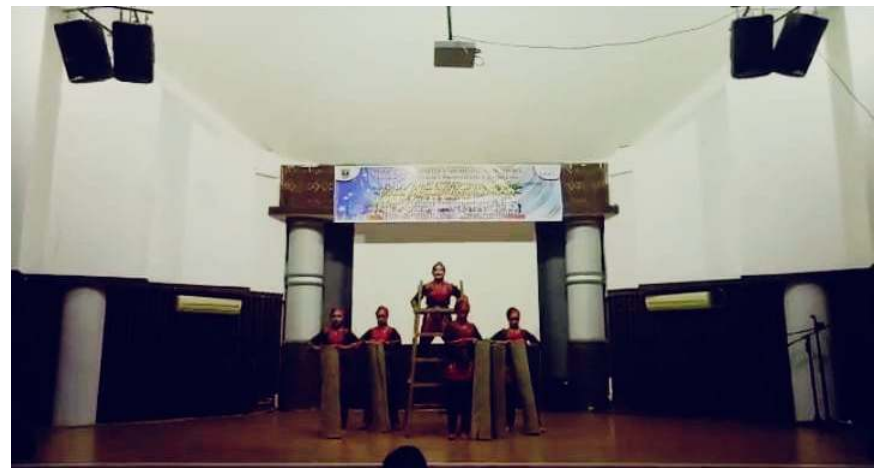

Figure 2. Participants of the Women's Group from SMP N 1 Payakumbuh City, Won 3rd Place at the West Sumatra Provincial Level FLS2N on August 42019

(Photo: Venny Rosalina, 2019)

On Figure 1 and Figure 2 show that until now there is no female dance group that can win the FLS2N at the provincial level to represent West Sumatra. If you look at the technical guidelines for the National FLS2N competition, it is determined that dancers can be male and female, for example in the technical guidelines for junior high school level 2019 with the theme Hero. When the concept chosen by the choreographer was about the Minangkabau heroine, one of them was Siti Manggopoh against the Dutch economic policy or it was called the Belasting (Armed) war. When viewed from this theme, of course the choreographer is able to interpret the ideas in an achievement of a dance work based on the concept of the work by considering its realization through dance choreographic elements. Therefore, in terms of quality and quantity of motion in a predetermined theme, it has the power / power of movement with strong dynamics in accordance with the theme in a war atmosphere. When this concept becomes a basic source of footing, then the character of the movement that will be raised is more agile or can be said to be more male characters, most likely the jury's perspective will judge that in female dancers the female side will disappear, if examined more deeply the criteria for judging more on the views of the individual judges than on the technical guidelines.

When this problem occurs in the past 3 years, schools or choreographers assume that male dancers have a great chance of winning, because there are not many rules that can be applied to male dancers, such as from the space to move: step or open legs the width or character that appears in the dance work itself. So the choreographer also chose to work on dance works with male dancers (safe zone). With this problem, it is possible to kill the female dancer character. This is evidenced in the Figure below, with male dance participants who won at the provincial level and were able to proceed to the national level representing West Sumatra. 


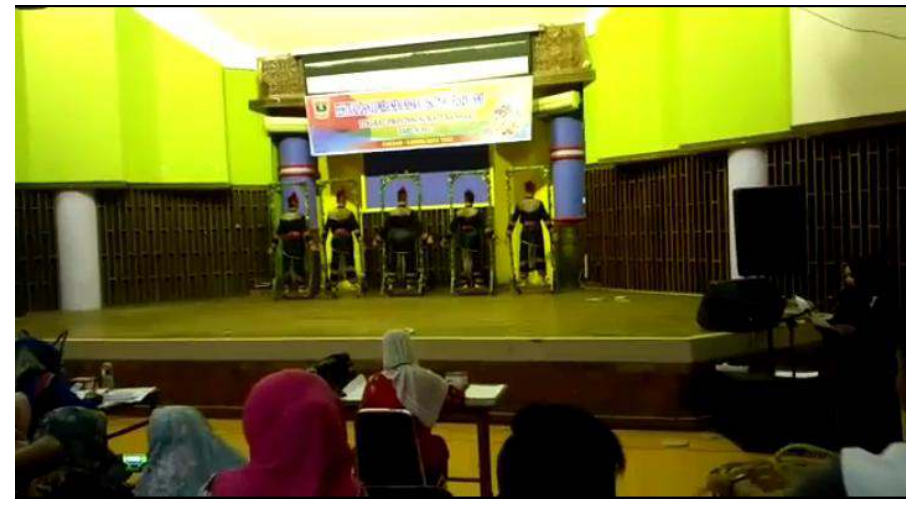

Figure 3. Male Group Participants from SMPN 2 Bukittinggi, received the 1st Place in the Province and proceed to the National Level at FLSN2N West Sumatra 2017

(Photo: Venny Rosalina, 2017)

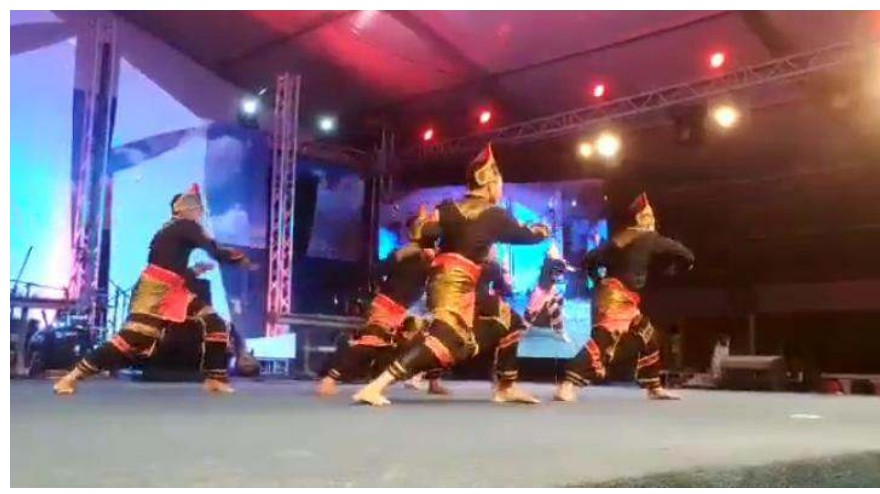

Figure 4. Male Group Participants from SMPN 2 BukitTinggi, received the 1st Place in the Province and proceed to the National Level at FLSN2N West Sumatra 2018

(Photo: Venny Rosalina, 2018)

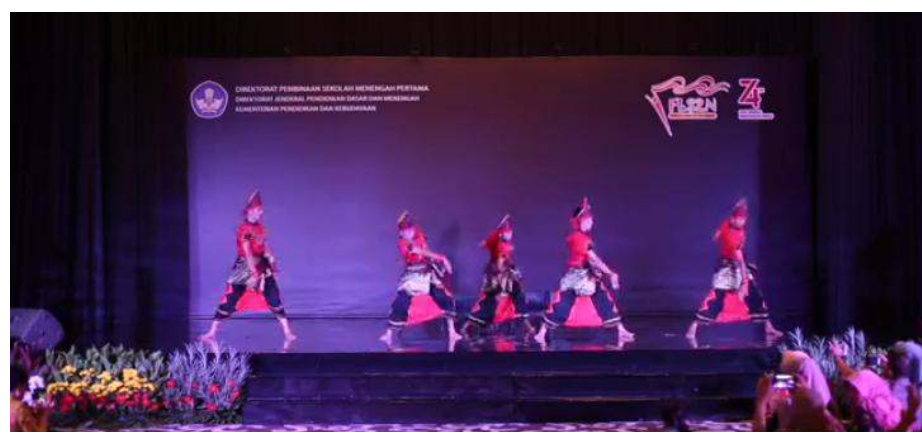

Figure 5. Male Group Participants from SMPN 1 Payakumbuh, received the 1st Place in the Province and proceed to the National Level at FLSN2N West Sumatra on September 17, 2019

(Photo: Ipraganis, 2019)

On Figure 3 to Figure 5 clearly proves that male dancers always win first place at the provincial level and come forward to represent West Sumatra. However, what needs to be studied more deeply is the assessment indicators listed on the FLS2N technical guidelines. 


\subsection{Jury Perspectives and Movement Creativity in Juknis FLS2N Dance Creativity in West Sumatra}

In general technical guidelines, it is stated that the indicators of assessment are wiraga, wirama, wirasa and dance (movement techniques) and regional identity (motion, contum, music, etc.), creativity and presentation. Then after winning at the provincial level will be continued at the national level. At the national level, the jury did not study basic matters such as ethics and regional aesthetics, but rather the concept of work and its relevance to the choreographic elements of a show. Basically, the support for a dance work in the FLS2N event is not based on gender, but based on the following understanding below.

\subsubsection{Wirama, Wiraga, and Wirasa}

Wirama is a sensitivity to the rhythm or music that accompanies dance. This becomes a force to adjust the dancer's tempo to the accompanying music. Wirama is the main assessment for the sensitivity of dance performers, an understanding of music must be instilled in students so that later when there is a match between movement and music that gives birth to a pleasant blend.

Wiraga is interpreted as the maximum or totality in moving. The seriousness of the dance participants is seen from the dance techniques instilled in students. To train the basic dances of junior high school children does require patience and teaching techniques. Having good technique is certainly not enough to get there, stamina and endurance also support the dancers to look fit when demonstrating the movements that have been trained so far.

Wirasa is the awareness to cultivate the taste in applying the movements presented. Without feeling, the dancer is no different than someone who is doing gymnastics. Rasa in this sense has a major war in realizing wirama and wiraga. Without wirasa, a dance performance is like losing a life or it can be said that it has no soul.

\subsubsection{Regional Identity (shows local culture)}

Developing local culture is the main target in technical guidelines every year, although it looks simple, it is actually difficult to apply regional identity. The coach's understanding always carries the contemporary style so that the overly acrobatic desire erodes the local cultural values which diminishes the regional identity itself.

\subsubsection{Creativity (motion, make-up, props, floor patterns and dramatic dance designs)}

Creativity determines whether a dance work is good or not. The lack of creativity means that dance cannot be enjoyed because there is no element of novelty. Property processing can give color to the work so that it gives birth to unexpected things. Property is also accompanied by grading the floor pattern so that there is unity in building dance drama.

\subsubsection{Presentation}

The presentation includes harmony, integrity and solidarity. This final assessment determines the extent of the process carried out to arrive at the competition. The trainer is required to generalize the dancers 'abilities so that no one or two dancers do not adequately accompany the other dancers' abilities.

In an effort to understand the jury's perspective as the key in assessing the winners, the researcher interviewed two judges who were representatives of academics and choreographers in West Sumatra. According to Indrayuda, a choreographer and lecturer at Sendratasik, UNP Padang's perspective on gender in FLS2N Dance Creativity, he said that: "In terms of power, gesture, flexibility and dancing techniques are more controlled by women than men, because women are physically easier to shape and process into an aesthetically pleasing and artistic technique. In terms of strength and speed, men still master it more than women. The philosophy in Minangkabau dance tradition and dance creations are based on silat movements so that the development of dominant dance movements is carried out by women with their novelty values related to the artistic aesthetics of a dance work based on aesthetics but not dominant in studying ethics. Minang dance originates or is based on the silat movements contained therein such as: vigilance, dexterity, sharpness, assertiveness and demonstration So that the characters displayed by female dancers will be carried away / still visible in the power of the female dancers. It's just that the appropriateness of the concept, theme and presentation of the dance as a whole becomes the main element in the assessment. Because the movements are considered less aesthetic not yet certainly not ethical." 
Meanwhile, Ali Sukri, a choreographer and dance lecturer at ISI Padangpanjang responded to another opinion about gender in FLS2N Tari, he said that: "There is no aspect in dance regarding the incest duo baleh. Indicators assess more on concepts, themes, movement techniques and appropriateness in their work. If the donation of the duo baleh becomes a consideration in dance, creativity will be limited." There is a slight difference between choreographers who come from educational academics and artistry, this character is of course very inherent and provides a different perspective from each of the judges, but this should not limit the judges in understanding and implementing technical guidelines for each competition at FLS2N.

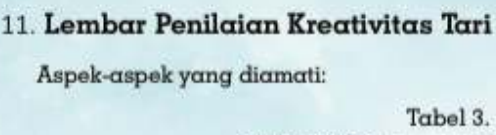

LEMBAR PENILAIAN KREATIVITAS TARI

\begin{tabular}{|l|l|l|l|l|}
\hline NO & IUDUL & ASPEK PENILAIAN \& BOBOT & \multicolumn{1}{|c|}{ INDIKATOR } & $\begin{array}{c}\text { SKOR } \\
(70-90)\end{array}$ \\
\hline & & $\begin{array}{l}\text { 1. } \\
\text { Identitas lokal genius da- } \\
\text { lam keberagaman }(10 \%)\end{array}$ & Sumber pijakan gerak & \\
\hline & $\begin{array}{l}\text { 2. } \\
\text { Kreativitas garap kelom- } \\
\text { pok (20\%) }\end{array}$ & $\begin{array}{l}\text { a. variasi gerak } \\
\text { b. musik tari } \\
\text { c. rias dan busana }\end{array}$ & \\
\hline & 3. $\begin{array}{l}\text { Kepenarian dan karakter } \\
(40 \%)\end{array}$ & $\begin{array}{l}\text { a. Kepenarian } \\
\text { b. karakter }\end{array}$ & \\
\hline & 4. Penyajian (30\%) & $\begin{array}{l}\text { a. harmoni } \\
\text { b. kesatuan } \\
\text { c. dinamika }\end{array}$ & \\
\hline
\end{tabular}

Keterangan:

Penilaian menggunakan sistem skor karena terdiri dari puluhan dan satuan. Perbedaan nilai antar peserta akan sangat bermakna meskipun di tingkat satuan. Penjelasan tentang nilai lebih mudah dipahami dengan bentuk skor.

\section{Jumlah Juri}

a. Jumlah juri yang dibutuhkan 3 orang dari unsur praktisi seni dan pendidik seni, terdiri atas: ketua (1 orang) dan anggota (2 orang).

b. Keputusan Juri tidak dapat diganggu gugat.

Figure 6. Judging Indicators and Criteria for the Jury in the 2018 FLS2N Dance Creativity Guideline based on the Ministry of Education and Culture

\section{Conclusions}

The conclusion that can be drawn from the above discussion is that the phenomenon of gender has become a topic of discussion for the last 3 years in the context of the FLS2N branch of dance creativity. This was evidenced by the male participants who always won first place at the provincial level and continued to the national level representing West Sumatra.

Several regulations regarding women in Minangkabau, such as the inclusion of duo baleh, are believed to be one of the main factors in the discussion of gender. Some judges are deemed to have removed the character or killed the potential of female Minang dancers, because the rules of the structure of women's life in Minangkabau are linked to the form of dance works so that the values that are considered odd / discordant become the benchmark in assessing dance work. Meanwhile, the choreographer who broke the dance in Minangkabau was a woman. For example, one of the moving stances or pitunggua is the basis for the Minang dance, while the jury from art educators prefers feminine movement patterns of women.

The main key that becomes an indicator in a dance competition should be more referring to Wiraga, Wirasa, Wirama and several other elements such as Regional Identity, Creation Creativity, and Dance Presentation as a whole although it must still contain the values, ethics and aesthetics of each region. 


\section{References}

Astuti, F. (2003). Performansi Perempuan Dalam Seni Pertunjukkan Minangkabau: Suatu Tinjauan Gender. Retrieved from http://repository.unp.ac.id/id/eprint/16945

Astuti, F. (2004). Perempuan Dalam Seni Pertunjukan Minangkabau: Suatu Tinjauan Gender. Yogyakarta: Kalika.

Hadi, Y. S. (2001). Pasang Surut Tari Klasik Gaya Yogyakarta: Pembentukan, Perkembangan, Mobilitas. Yogyakarta: Lembaga Penelitian Institut Seni Indonesia Yogyakarta.

Indrayuda, I. (2015). Continuity of Tradition Dance: Acedemicians' Intervention on Artists and Performing Arts Groups. Harmonia: Journal of Arts Research and Education, 15(2). https://doi.org/10.15294/harmonia.v15i2.4454

Indrayuda, I. (2017). The Existence of Local Wisdom Value Through Minangkabau Dance Creation Representation in Present Time. Harmonia: Journal of Arts Research and Education, 16(2), 143-152. https://doi.org/10.15294/harmonia.v16i2.6146

Indrayuda, I., \& Ardipal, A. (2017). Women domination in the Galombang dance: between the customary idealism and the market use. Harmonia: Journal of Arts Research and Education, 17(2), 153-162. https://doi.org/10.15294/harmonia.v17i2.10724

Kuardhani, H. (2000). Teater Rakyat Janger Banyuwangi Ungkapan Keberadaan Masyarakat Pendukungnya (Unpublished master's thesis). Universitas Gadjah Mada, Yogyakarta.

Manab, H. A. (2015). Penelitian Pendidikan Pendekatan Kualitatif. Yogyakarta: Kalimedia.

Margono, S. (2005). Metodologi Penelitian Pendidikan. Jakarta: Rineka Cipta.

Sinaga, F. S. S. (2016). Musik Trunthung Sebagai Media Ekspresi Masyarakat Warangan. Seminar Antarbangsa, 161-174. https://doi.org/10.31227/osf.io/wc4vy

Sinaga, F. S. S., Maestro, E., Winangsit, E., \& Yensharti, Y. (2019). Learning and Singing: Thematic Children Songs in Kindergarten. Proceedings of the Seventh International Conference on Languages and Arts (ICLA 2018), 143-151. https://doi.org/10.2991/icla-18.2019.23

Sriyadi, S. (2013). Sanggar Tari Sebagai Patner Dalam Pendidikan Sekolah Kejuruan Tari. Abdi Seni, 5(1).

Storey, J. (2018). Cultural Theory and Popular Culture. In Cultural Theory and Popular Culture (8th ed.). https://doi.org/10.4324/9781315226866

Tomars, A. (1964). Class Systems and the Arts. In W. J. Cahnman \& A. Boskoff (Eds.), Sociology and History: Theory and Research (pp. 472-483). New York: The Free Press of Glencoe. 